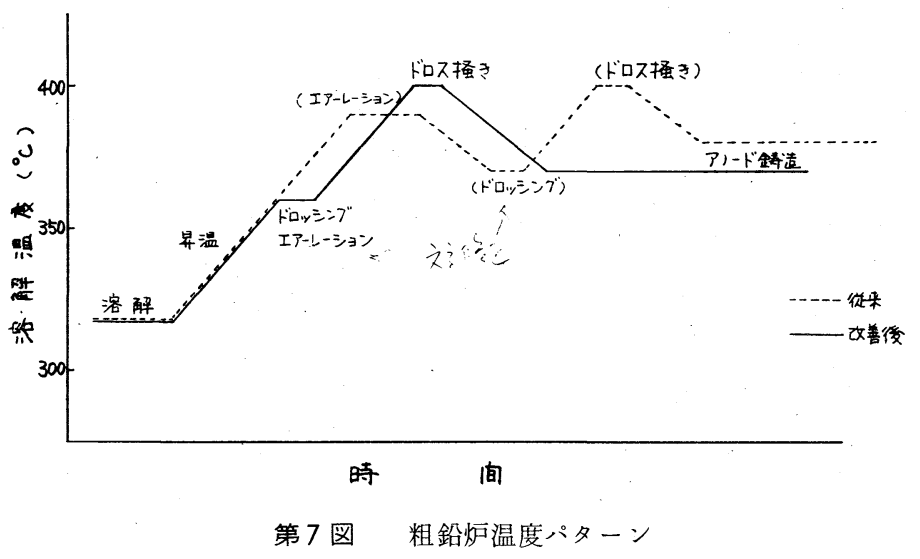

場では省エネルギー対策の大きな柱の一つとして溶鉱炉排ガス (LCVガス：Low Calorific Value gas) の有効利用が揭げ られ重油代替燃料としての検討が進められていた。このガスは $\mathrm{CO} 22 \sim 24 \%, \mathrm{H}_{2} 1 \%, \mathrm{CO}_{2} 10 \%, \mathrm{~N}_{2} 65 \sim 67 \%$ の組成を 有し, 発熱量は $720 \mathrm{kcal} / \mathrm{Nm}^{3}$ のいわゆる低カロリーガスで, 然 焼の安定性, LCV ガス専焼など不安要素があつたが, メタル保持 炉での試験操業で良好な結果が得られたので工場内のメタル保持 炬および溶解炬のほとんどをLCV ガス 燃焼方式に切替えること とした。

電解工場においても稼動率の低い種板炉を除いて粗鉛炉 ( 2 炉)
と型鉛炉を L C V ガス燃焼方式に切替えた。なお溶鉱炉 が 2 週間毎に定期休転を実施することもあつてバーナ型 式はガスーオイルコンビネーションタイプのものを取付 け，L C V ガスおよび重油それぞれの専焼と L C Vガス と重油の混焼も可能なタイプにしている。この転換起業 により電解工場で使用していた重油の約 $80 \%$ が削減で き大幅な省エネルギーを達成した。

\section{6. 結言}

以上住鉱アイ・エス・ピー（株）の鉛電解における添 加剤の変更と省エネルギー対策等を中心に操業の概略に ついて述べたが，添加剤変更による効果として

(1) 臭気に対する作業環境の改善

(2) 年間 4 百万円の添加剂費用の削減

(3) 年間 3 百万円の電力代の削減

をはかることができた。

また省エネルギー対策により年間 13 百万円 の重油代を削減す ることができた。

さらに操業改善, 設備合理化等に取組み, 高効率かつ低コスト の鉛電解操業を目指し努力していきたい。

1）公開特許公報 昭 $54-11829$

$$
\text { 参 考 文 献 }
$$

2) C. J. Krauss : JOM 28 No.12 $4 \sim 9$ (1976)

\title{
（7）銅電解工場種板工程の改善について
}

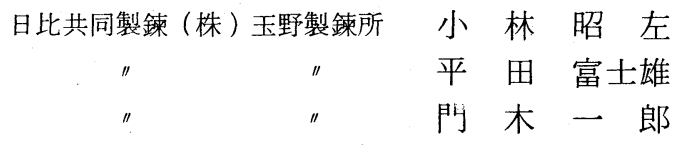

\section{1.はじめに}

玉野製鍊所銅電解工場は, 周期的反転電流 (PRC)による高電 流密度電解法を採用しているため, 種板工程についても建設計画 の時点から, 良質な種板が得られるよう特段の配慮がなされてい た。

高電流密度電解においては, 特に種板の品質は操業成績に及ぼ す影響が大きく, 操業開始の昭和 47 年. 1 月 以後も種々の改善を 実施してきた。その中で最近の主なものについて，その概要を述 ベることとする。

\section{2. 種板品質の均一化対策の経䋎}

\section{$2 \cdot 1$ 種板工程の基本的な考え方}

銅電解工場における種板工程は, 通常, 良質な電気銅を生産す るために必要な陰極板を供給することが目的であり，そのために 必要な種板の品質として，一般的に

(1) 形状が一定であること。

(2) 電気銅品位と同程度以上の品位を有すること。

(3) 肉厚のバラッキが少ないこと。

(4) 硬さが一定であること。

(5) 表面が平滑であること。

等が要求される。

当所の場合高電流密度法を採用しているため, 特に種板品質の 均一性に対する要求は非常に厳しく, これらを満足できるか否か
は陰極板の垂直性の良否に直接影響し，操業成績，あるいは電気 銅品質に対して大きな影響を及ぼすため，建設計画の段階から種 種検討が重ねられた。その結果以下を基本として建設された。

(1) 整流器および電解液循環回路は, P R C 回路と切り離し, 種板回路専用に設けること。

（2）種板用大型アノードを専用に鋳造使用すること。

（3）剝取装置は，母板および種板の損傷回避，あるいは選別が 困難な自動化, 機械化は避け, トロリーコンベヤ方式の手動剝取 方式とすること。

(4) Cup Bus を使用し，槽内各電極を流れる電流のバラッキを 極力小さく抑えること。

しかしDip-Forming 向け等, ますます㛜しくなる電気銅品質 を確保し, かつ電解操業成績の向上を図るには, さらに均一な品 質の種板を得ることが必要となり，日常管理も含めきめ細か、管 理改善を実施してきた。

\section{$2 \cdot 2$ 種板形状の一定化対策}

種板の形状不均一を生じる要因として最も大きなものに，母板 周縁部絶縁材の不良がある。絶縁材の不良は，

（1）種板寸法が不均一になるため，陰極板の形状が悪化し，製 品品質，特に外観を損うこと。

（2）剝離困難な種板が生じるため, 強引な剥離によつて種板形 状を悪化させ，陰極板の垂直性を著しく悪化させ陰極板として使 用不能となる上, 絶縁材の損傷を進行させるため修復枚数を増加 せねばならず，かなりの時間と労力が必要となること。 


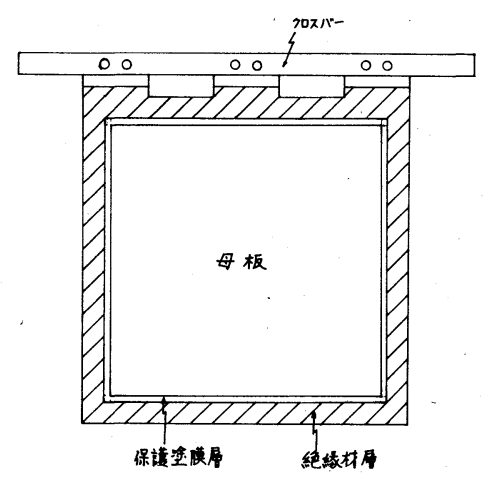

等, その影響が大きいため, 種板形状の一定化対策として 母板周縁部絶縁材の寿命延長対策を実施した。

（1）母板と絶縁材との境界面に耐酸性, 耐電気絶縁性で かつ接着性の塗膜を被覆した。これにより母板と周縁絶縁 材との間隙に電解液が入り込み電流が流れることによる電 解析出を防止するとともに, 電着種板と絶縁材とが直接接 触しないため, 絶縁材の寿命を向上させることができた。 第 1 図に絶縁材層および保護塗膜層を設けた母板略図を示 す。

（2）絶縁材料として従来より使用していた硬質塩化ビニ ールシートを, 熱的変化に強く, 耐衝撃性にも優れている 強化塩化ビニールシートに変更し, 種板電解ならびに剥取 作業に伴う温度変化による絶縁材劣化の進行, あるいは機械的な 損傷を防止し，絶縁材の寿命向上を図つた。

（3）母板絶縁材の修復作業は, 従来作業能率を高めるため, 絶 縁材の剥ぎ取り, 絶縁材の接着, および母板面研磨の 3 工程をお のおの分担作業で行なつていたが，これらの 3 工程の作業を同一 作業者に行なわせる責任管理方式に改めた。

以上の結果, 母板絶縁材の寿命は改善され, 平均寿命 $6 \sim 10$ 力 月の母板が安定して確保され, 種板形状の一定化に大きく貢献し た。

\section{$2 \cdot 3$ 種板硬さの均一化対策}

種板硬さを不均一にする要因としては, 主に種板の硬度のバラ ッキによるものと, 肉厚のバラッキによるものとがあるが, 両者 とも陰極板の垂直性に対して大きな影響を及ぼす上, 電気銅品質 および電解操業成績に直接関係するため, 種板の硬さを一定に維 持することを基本に改善を進めた。

（1）種板アノード入替作業ならびに槽底スライム抜き出し作業 に伴う電解液繰りの関連から, 種板回路電解液の補加用として添 加剂添加割合の異なる P R C 回路電解液を供用していたが, 電着 種板の硬度が不安定となるため, この補給を廃止した。

(2) 種板電解停電日の添加剤消耗量を実際の電着状態をもとに 調查, 試験し, 種板回路の添加剤添加割合の一定化を図つた。

(3) 種板剝離用塗布剂の濃度 $(\mathrm{pH})$ および温度のバラッキが, 従来おのおの $\mathrm{pH}=7 \sim 9, .45 \sim 65^{\circ} \mathrm{C}$ と比較的大きかつたため, 剥離不良や硬度の不均一が生じていたので, 塗布剤の補給方法を バッチ式から連続式に改善するとともに, 自動温度調節方式とし, 塗布剤を $\mathrm{pH}=8 \sim 8.5$, 温度 $=55 \sim 60^{\circ} \mathrm{C}$ に維持し安定化を図つ た。

（4）種板の重量を，母板各面について 1 槽単位で定期的に測定 し, その結果を基にして電極間隔を修正するようにし, 種板肉厚 の均一化を図つた。

\section{3. 操 業 実 績}

\section{$3 \cdot 1$ 母板絶縁材の寿命}

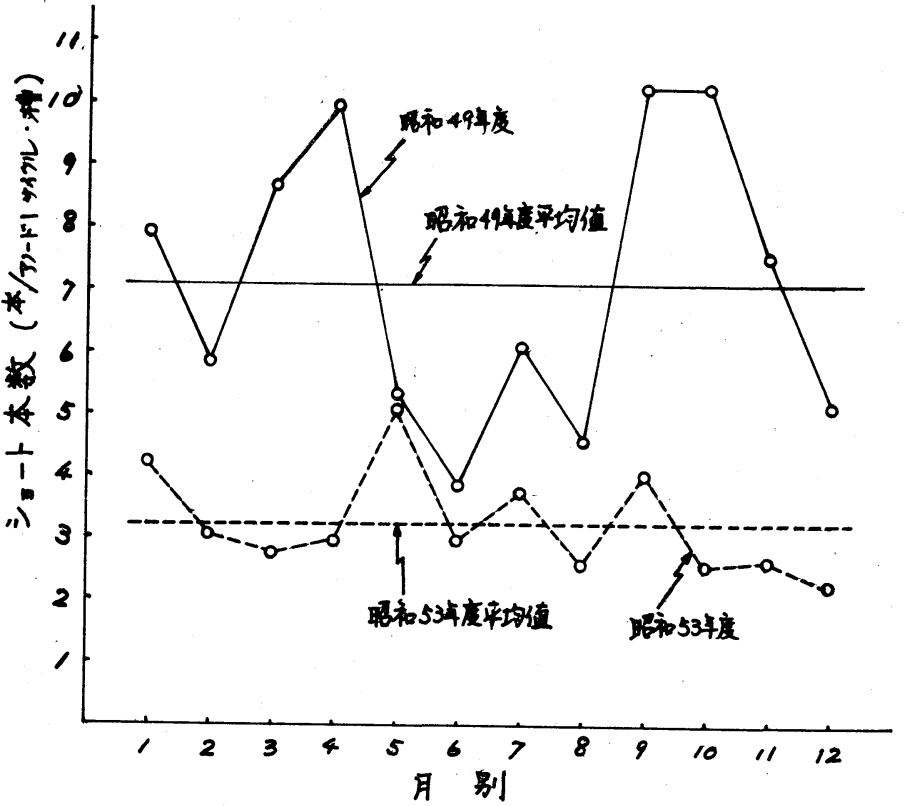

注 1 ショート本数はアノードライフ 1 回分， 1 槽当りの総数 の月平均値

注 2 昭和 49 年, 53 年各平均 $D_{k} \fallingdotseq 330 \mathrm{~A} / \mathrm{m}^{2}$ 第 2 図 $シ ョ$-ト本数

第 1 表 母板絶縁材の寿命

\begin{tabular}{c|c|c}
\hline & 昭和 50 年 & 昭和 52 年 \\
\hline 1 $\sim$ 6月平均 & 213 日 & 230 日 \\
$7 \sim 12$ 月平均 & 223 & 246 \\
\hline 平 $\quad$ 均 & 218 日 & 238 日 \\
\hline
\end{tabular}

第2表 母 板 仕 様

\begin{tabular}{|c|c|c|c|}
\hline 摘 & & 要 & 様 \\
\hline $\begin{array}{l}\text { 母 } \\
\text { 絶 } \\
\text { 塗 }\end{array}$ & $\begin{array}{l}\text { 縁 } \\
\text { 布 }\end{array}$ & $\begin{array}{l}\text { 板 } \\
\text { 材 } \\
\text { 膜 }\end{array}$ & $\begin{array}{l}\text { 圧延銅板, } 1080 \times 1080 \times 4 \\
\text { 強化塩化ビニールシート } \\
\text { カシ塗料 }\end{array}$ \\
\hline
\end{tabular}

第3 表 母板各面の種板重量測定結果例

\begin{tabular}{c|c|c|r}
\hline 鋳型面種板 & 湯 面 種 板 & 平均重量差 & 重量差のバラッキ \\
\hline $6.19 \mathrm{~kg} /$ 枚 & $6.21 \mathrm{~kg} /$ 枚 & $0.02 \mathrm{~kg} /$ 枚 & $\sigma=0.11 \mathrm{~kg}$ /枚 \\
\hline
\end{tabular}

（注 1 ）鋳型面種板とは, アノードの鋳型面に対面した母板 面に電着した種板で, 1 槽当りの平均重量を示す。

（注 2 ）湯面種板とは,アノードの湯面側に対面した母板面 に電着した種板で, 1 槽当りの平均重量を示す。

(注3) 重量差のバラッキは 53 年に測定した 9 槽分のバラ ッキ

第 1 表に昭和 50 年と昭和 52 年における母板絶縁材の平均寿命 を示す。また母板仕様を第 2 表に示す。なお保護塗布膜の効果は， 昭和 50 年 実績に含まれでいるが, 保護塗布膜を使用しない場合 の絶縁材の平均寿命は $3 \sim 4$ カ月である。

\section{$3 \cdot 2$ 種板硬さの均一化効果}

種板の硬さの判定は作業者の感覚的な判断に頼つているが，日 常管理としては, 陰極板の垂直性ならびにショート本数の増減等 も間接的判断として役立つている。第 2 図にP R C 電解における ショート本数を, 操業度のほぼ等しい昭和 49 年と昭和 53 年で比 較し示す。平均值で約 $55 \%$ 減少しており, 電解条件, アノード品 質, その他種々の電解条件向上要因等が含まれてはいるが, 種板 
第 4 表 種板工程の設備概要

\begin{tabular}{|c|c|c|}
\hline 設 備 名 & 数 & 様 \\
\hline 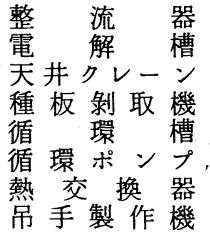 & $\begin{array}{r}1 \\
36 \\
1 \\
1 \\
3 \\
2 \\
2 \\
2\end{array}$ & $\begin{array}{l}22.5 \mathrm{kA} \times 20 \mathrm{~V} \\
1.2 \mathrm{~mW} \times 4.86 \mathrm{~mL} \times 1.3 \sim 1.4 \mathrm{mH} \\
5 \mathrm{t}, \text { マントロリー式 } \\
\text { トロリーコソベヤ式, 能力 } 2000 \text { 枚 } / \text { 日 } \\
16 \mathrm{~m}^{3} \times 2 \text { 槽, } 16.8 \mathrm{~m}^{3} \times 1 \text { 槽 } \\
1.5 \mathrm{~m}^{3} / \mathrm{min} \times 15 \mathrm{mH} \text {, 㹂型沈水式 } \\
\text { 伝熱面積 } 22.3 \mathrm{~m}^{2} / \text { 基 } \\
\text { スリッター式, 切断幅 } 120 \mathrm{~mm}, 450 \mathrm{~mm}\end{array}$ \\
\hline
\end{tabular}

第 5 表 種板工程の電解条件

\begin{tabular}{|c|c|c|}
\hline 摘 & 単 位 & \\
\hline 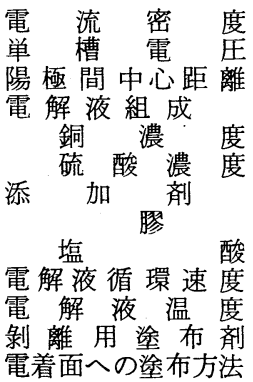 & $\begin{array}{c}\mathrm{A} / \mathrm{m}^{2} \\
\mathrm{~V} \\
\mathrm{~mm} \\
\mathrm{~g} / l \\
\mathrm{~g} / l \\
\mathrm{~g} / \mathrm{t} \\
\mathrm{g} / \mathrm{t} \\
l \% \mathrm{~min} \\
{ }^{\circ} \mathrm{C}\end{array}$ & $\begin{array}{l}D_{k}=221 \\
0.28 \sim 0.29 \\
100 \\
38 \sim 39 \\
180 \sim 185 \\
100 \\
80 \\
25 \\
56 \sim 58 \\
\text { 石けん液 } \\
\text { スプレー万式 }\end{array}$ \\
\hline
\end{tabular}

第 6 表 種板工程人員配置

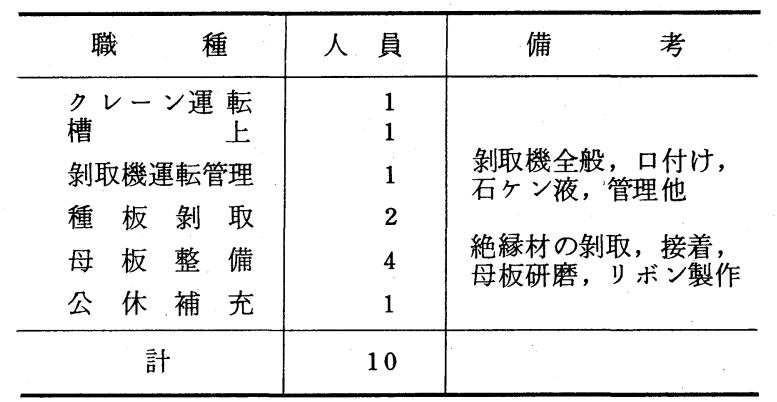

硬さの均一化が相当貢献しているのは事実である。また第 3 表に は, 母板各面の電着種板重量測定結果の一例を示す。

\section{$3 \cdot 3$ その他操業実績}

第 4 表に種板工程の設備仕様を, 第 5 表に種板工程の電解条件 を，第 6 表に種板工程の人員配置をおのおの示す。

$$
\text { 4. おわりに }
$$

以上, 高電流密度電解においてほぼ満足すべき品質の種板が得 られたことは, 将来ますます厳しくなる電気銅品質に対処し, 電 解操業成績を向上させる上で, 種板工程がいかに重要であるかを 意味するものであり, 今後ともこの点を十分認識し, さらに綿密 な管理改善を進めていきたい。

（8）銅精鉱の流動焙焼の操業と解析

\section{1. まえがき}

直島製鍊所では, 現在, 反射炉法と連続製銅法の $2 つ$ 異なつ た方式で銅製鍊を行なつている。

そのうちカルサイン装入反射炉系は, 昭和 44 年 スタート以来, 順調な操業を行なつており, 現在, 8,000 t/月, の鉱石出アノ一 ドを生産している。この反射炉操業の概要については既に発表さ れているが, ${ }^{1) 2}$ 今回は, 銅鉱部分焙焼を行なう流動炉の操業につ いて報告したい。

流動炉では安定した高濃度の $\mathrm{SO}_{2}$ ガスが硫酸工場へ供給され, また, 生成したカルサインは, 温度が高く, 反射炬での溶解効率 は良く, 燃料率は生鉱装入反射炉に比較して低いという利点があ る。しかし, 一方, 反射炬で一定鈹品位を維持するため, 流動炉 では鉱石の酸化をコントロールし, かつ, 流動層が安定になるよ

\section{うに操業をコントロールしなければならない。}

また, 当所では原料鈗石の 9 割以上が, 各種の輸入鉣であり, 流動炉操業に重要な影響を与える原料の粒子径, 主成分であると ころの $\mathrm{Cu}, \mathrm{S}, \mathrm{Fe}$ 等が常に変動することは避けられない。

ここではこうした変動に対処するための操業コントロールにつ き解析を試みた。

\section{2. 流動炉操業について}

銅精鉱, 転炉鍰浮選鉱, および溶剂は, 調合ヤードに積まれ, リクレーマで切出される。均一にブレンディングされた調合鉱は テーブルフィーダにより，一定スピードで 4 個のシュートから流 動炉へ装入され，炬底羽口から吹込まれる空気により部分焙焼さ れる。焙焼されたカルサインは, 大部分, 炬からガスとともに排 出され, サイクロン, コットレルで捕集後, 反射炬へ送られる。
第 1 表 流動炉操業例

\begin{tabular}{|c|c|c|}
\hline 項 & 単 位 & 実 績 \\
\hline 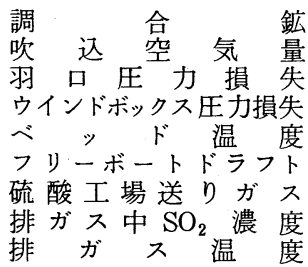 & $\begin{array}{c}\text { 湿量 } \mathrm{t} / \mathrm{h} \\
\mathrm{Nm}^{3} / \mathrm{min} \\
\mathrm{mm} \mathrm{Aq} \\
\mathrm{mm} \mathrm{Aq} \\
{ }^{\circ} \mathrm{C} \\
\mathrm{mm} \mathrm{Aq}^{3} \\
\mathrm{Nm}^{3} / \mathrm{min} \\
{ }_{\%}^{\circ} \\
{ }^{\circ} \mathrm{C}\end{array}$ & $\begin{array}{r}55 \\
320 \\
900 \\
2,600 \\
630 \\
+\quad 0 \\
600 \\
10 \\
300\end{array}$ \\
\hline
\end{tabular}

流動炉 1次サイクロン 2次サイタン ボイラ 3次サイフロンットレル

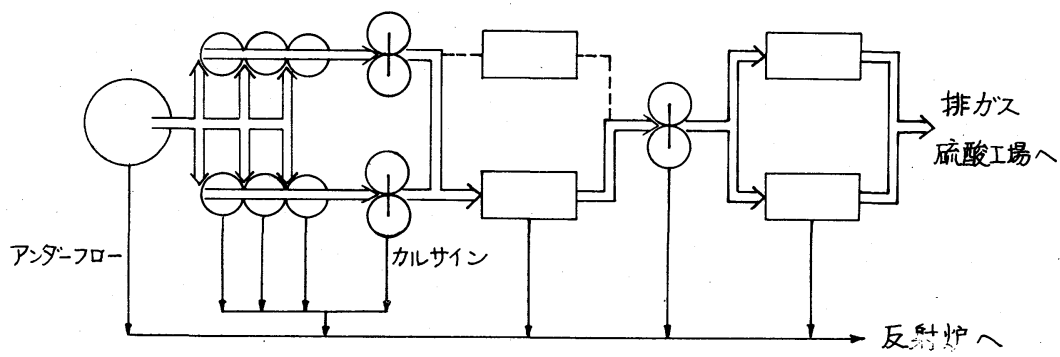

第 1 図 流動焙焼系フローシート 